\title{
Adverse reactions to influenza vaccine in elderly people: randomised double blind placebo controlled trial
}

\author{
Th M E Govaert, G J Dinant, K Aretz, N Masurel, M J W Sprenger, J A Knottnerus
}

\begin{abstract}
Objective-To assess the frequency and type of side effects after influenza vaccination in elderly people.

Design-Randomised double blind placebo controlled study.

Setting-15 general practices in the southern Netherlands.

Subjects-1806 patients aged 60 or older, of whom 904 received influenza vaccine and 902 placebo.

Main outcome measures-Adverse reactions reported on postal questionnaire completed four weeks after vaccination.

Results-210 (23\%) patients given vaccine reported one or more adverse reactions compared with $127(14 \%)$ given placebo. The frequency of local adverse reactions were $17.5 \%$ in the vaccine group and $7.3 \%$ in the placebo group $(p<0.001)$. There was no difference in systemic adverse reactions $(11 \% v$ $9 \cdot 4 \% ; p=0.34)$. In general, men reported fewer side effects than women.

Conclusion-Only local side effects were more common in vaccinated patients and all side effects were mild.
\end{abstract}

Department of General

Practice, University of Limburg, Maastricht, Netherlands

Th M E Govaert, general practitioner

G J Dinant, general

practitioner

J A Knottnerus, professor of general practice

$\mathrm{K}$ Aretz, research assistant

Department of Infectious Diseases Epidemiology, National Institute of Public Health and Environmental Protection, Bilthoven, Netherlands

M J W Sprenger, medical virologist

Department of Virology and WHO Influenza

Centre, Erasmus

University, Rotterdam, Netherlands

N Masurel, professor of

medical virology

Correspondence to:

Dr Govaert, Mauritsweg 3,

NL-6171 RM Stein,

Netherlands.

BMF 1993;307:988-90

terly people are at high risk of morbidity mortality related to influenza, ${ }^{17-21}$ and vaccination of all people aged over 60 years has been advocated. ${ }^{22} \mathrm{We}$ studied the specific adverse reactions to influenza vaccination in elderly people and how often they occurred. We also examined whether the occurrence of side effects was influenced by the patient's risk status, age, and sex and by previous vaccination.

\section{Patients and methods}

The study was conducted in the winter of 1991-2 and involved 31 general practitioners in 15 practices. The total practice population was 68988 patients. Patients aged younger than 60 , those who were expected to belong to one of the high risk groups, ${ }^{23}$ and those living in an old people's or nursing home were excluded. Of the remaining 9907 patients, 1838 patients $(18 \cdot 6 \%)$ agreed to participate. A total of 185 patients had been vaccinated in 1989 and 1990. Cardiological, pulmonary, or metabolic problems were reported by 490 patients but their general practitioners considered that these conditions were not severe enough to make vaccination mandatory. The general practitioners had different interpretations of high risk patients. To assess the effect of risk status on the frequency and nature of side effects we divided patients into four morbidity categories: heart condition, lung condition, diabetes mellitus, and other conditions or healthy.

In accordance with the advice of the World Health Organisation and the Dutch Health Council we used a purified split virion vaccine containing A/Singapore/ 6/86 (H1N1), A/Beijing/353/89 (H3N2), B/Panama/ $45 / 90$, and B/Beijing/1/87, all at a strength of $15 \mu \mathrm{g}$ haemagglutinin. Physiological saline solution was used as placebo. Between 1 November 1991 and 15 November 1991 the participants received an injection in the deltoid muscle with either vaccine or placebo, according to a stratified randomisation schedule. We used four strata, one for each of the morbidity categories. Four weeks later the subjects were sent a questionnaire asking about side effects within 48 hours after vaccination. Questionnaires were analysed by researchers blind to vaccination status.

\section{STATISTICAL ANALYSIS}

We used the $\chi^{2}$ test for independent proportions or Fisher's exact test if the number of expected observations was below six in one or more cells. Multiple logistic regression analysis was used to analyse the joint effect of the independent variables (current vaccination status (vaccine or placebo), risk status, sex, age, and previous vaccination) on all side effects, systemic side effects, and local side effects. The analyses were done on a VAX mainframe computer with the BMDP-LR program.

The protocol was approved by the medical ethics committee of the University of Limburg and the University Hospital, Maastricht. Informed consent was obtained from all subjects. 
was found in the frequency of side effects between the vaccine and placebo groups (19/92 (21\%) v 19/91 $(21 \%) ; p=0.97)$. In general, the difference between the effect of vaccination in the vaccine and placebo groups decreased with increasing age. Women reported substantially more side effects than men $(148(30 \%) v 62$ $(15 \%))$. All adverse reactions were transitory and mild.

Table III gives the results of the multiple logistic regression analysis. Vaccination had a significant effect on only local adverse reactions (odds ratio $=2 \cdot 62$ ). The presence of a lung or, to a lesser degree, heart condition was an extra risk factor (odds ratio $=2.23$ and 1.56 respectively). Side effects remained less common in men than women after adjustment for other factors (odds ratio $=0.47$ for systemic reactions and 0.38 for local reactions). In general, older age seemed to have a slightly negative effect. Occurrence of systemic side effects was not influenced by vaccination except in patients with a lung condition.

\section{Discussion}

Most studies have found a low incidence of local (up to $20 \%$ ) and systemic (up to $5 \%$ ) adverse reactions to influenza vaccination. ${ }^{31013141623}$ However, a Canadian survey showed local side effects in $87 \%$ of patients and systemic effects in $49 \% .{ }^{15} \mathrm{We}$ found that systemic side effects were equally common in the vaccine and placebo groups. This observation has been made in other studies. ${ }^{10-141617}$ Only a few studies have used similar methods to ours..$^{1316} 17$ These studies, however, were conducted on veterans (nearly all men) ${ }^{13}$ young subjects, ${ }^{16}$ and residents of nursing homes ${ }^{17}$ whereas our subjects were representative of the general population.

We studied healthy subjects aged 60 or above. To our knowledge there was no selection on the basis of

TABLE I-Characteristics of patients randomised to receive influenza vaccine or placebo. Values are numbers (percentages)

\begin{tabular}{lcc}
\hline & $\begin{array}{c}\text { Vaccine group } \\
(\mathrm{n}=927)\end{array}$ & $\begin{array}{c}\text { Placebo group } \\
(\mathrm{n}=911)\end{array}$ \\
\hline Risk status: & & \\
Heart condition & $125(13 \cdot 5)$ & $124(13 \cdot 6)$ \\
Lung condition & $105(11 \cdot 3)$ & $95(10 \cdot 4)$ \\
Diabetes mellitus & $21(2 \cdot 3)$ & $20(2 \cdot 2)$ \\
Others & $676(72 \cdot 9)$ & $672(73 \cdot 8)$ \\
Sex: & & \\
Male & $420(45 \cdot 3)$ & $449(49 \cdot 3)$ \\
Female & $507(54 \cdot 7)$ & $462(50 \cdot 7)$ \\
Age (years): & & \\
$60-64$ & $368(39 \cdot 7)$ & $396(43 \cdot 5)$ \\
$65-69$ & $281(30 \cdot 3)$ & $249(27 \cdot 3)$ \\
$70-74$ & $176(19 \cdot 0)$ & $177(19 \cdot 4)$ \\
$75-79$ & $66(7 \cdot 1)$ & $61(6 \cdot 7)$ \\
$80-84$ & $29(3 \cdot 1)$ & $19(2 \cdot 1)$ \\
$85-91$ & $7(0 \cdot 8)$ & $9(1 \cdot 0)$ \\
Previously vaccinated: & $118(12 \cdot 7)$ & $120(13 \cdot 2)$ \\
Yes & $809(87 \cdot 3)$ & $791(86 \cdot 8)$ \\
No & & \\
\end{tabular}

\section{Practice implications}

- Uptake of influenza vaccination in elderly people is low, partly because patients are often concerned about the side effects

- In this study local effects were significantly less common in the placebo group than in the vaccine group but no difference was found in systemic effects

- All side effects were mild in nature and transitory

- Elderly patients can be reassured about side effects of vaccination

susceptibility to adverse reactions. We assessed side effects by a questionnaire sent to all subjects four weeks after vaccination. This method was chosen because of practical considerations. Although a questionnaire may result in less accurate reporting, alternative methods, such as keeping a diary, can easily lead to overreporting. Because our subjects received the questionnaires well after vaccination they were not focusing on side effects during the first $\mathbf{4 8}$ hours. After four weeks they probably remembered only the "real" adverse reactions. The double blind design of the trial excluded recall bias: differences could be related only to the subject's vaccination status.

Non-protein impurities can get into both vaccines and placebos during preparation. These produce side effects in both vaccine and placebo groups. ${ }^{1011}$

We found that the differences between patients given vaccine and those given placebo decreased with increasing age. This finding could have been biased by the fact that there were fewer patients in the older age groups.

Among the subjects who had been previously vaccinated we found no significant difference in the number of adverse reactions between those given vaccine and those given placebo. This group of subjects may have acquired some immunity from previous vaccinations that reduced the antigenic effect of the vaccine. ${ }^{24} 25$

Women reported more side effects than men. Regression analysis also showed that female sex was the main covariable in suffering adverse reactions. Other studies have also suggested that the side effects are more common in women than in men. ${ }^{12} 2627$ However, we found that fever-the only adverse reaction that can be observed objectively-was reported by similar numbers of men and women (seven men and 11 women, $p=0.63$ ). Although the difference between men and women is still unexplained, it should be recognised in future studies into side effects.

TABLE II-Numbers (percentages) of all patients * and of patients at potential risk who reported local or systemic adverse reactions

\begin{tabular}{|c|c|c|c|c|c|c|}
\hline \multirow[b]{2}{*}{ Reactions } & \multicolumn{2}{|c|}{ Vaccine group } & \multicolumn{2}{|c|}{ Placebo group } & \multicolumn{2}{|c|}{$\mathrm{p}$ Value } \\
\hline & $\begin{array}{l}\text { All patients } \\
(n=904)\end{array}$ & $\begin{array}{c}\text { Patients at } \\
\text { potential risk } \\
(\mathrm{n}=246)\end{array}$ & $\begin{array}{c}\text { All patients } \\
(\mathrm{n}=902)\end{array}$ & $\begin{array}{c}\text { Patients at } \\
\text { potential risk } \\
(n=234)\end{array}$ & All patients & $\begin{array}{l}\text { Patients at } \\
\text { potential risk }\end{array}$ \\
\hline Local reactions: & $158(17 \cdot 5)$ & $52(21 \cdot 1)$ & $66(7 \cdot 3)$ & $20(8 \cdot 5)$ & $<0.001$ & $<0.001$ \\
\hline Swelling & $66(7 \cdot 3)$ & $25(10 \cdot 2)$ & $8(0.9)$ & $2(0.9)$ & $<0.001$ & $<0.001$ \\
\hline Itching & $41(4 \cdot 5)$ & $18(7 \cdot 3)$ & $13(1 \cdot 4)$ & $6(2 \cdot 6)$ & $<0.001$ & 0.02 \\
\hline Warm feeling & $43(4 \cdot 8)$ & $17(6 \cdot 9)$ & $14(1 \cdot 6)$ & $4(1 \cdot 7)$ & $<0.001$ & 0.01 \\
\hline Pain when touched & $94(10 \cdot 4)$ & $30(12 \cdot 2)$ & $29(3 \cdot 2)$ & $10(4 \cdot 3)$ & $<0.001$ & 0.00 \\
\hline Constant pain & $17(1.9)$ & $6(2 \cdot 4)$ & $8(0.9)$ & $3(1 \cdot 3)$ & 0.07 & 0.50 \\
\hline Discomfort & $23(2 \cdot 5)$ & $4(1 \cdot 6)$ & $19(2 \cdot 1)$ & $4(1 \cdot 7)$ & 0.53 & 1.00 \\
\hline Systemic reactions: & $99(11 \cdot 0)$ & $27(11 \cdot 0)$ & $85(9 \cdot 4)$ & $28(12 \cdot 0)$ & 0.34 & 0.73 \\
\hline Fever & $12(1 \cdot 3)$ & $2(0.8)$ & $6(0 \cdot 7)$ & $2(0.9)$ & $0 \cdot 15$ & 1.00 \\
\hline Headache & $44(4 \cdot 9)$ & $13(5 \cdot 3)$ & $35(3.9)$ & $15(6.4)$ & 0.30 & 0.60 \\
\hline Malaise & $58(6 \cdot 4)$ & $14(5 \cdot 7)$ & $50(5-5)$ & $17(7 \cdot 3)$ & 0.45 & 0.50 \\
\hline Other complaints & $33(3 \cdot 7)$ & $8(3 \cdot 3)$ & $31(3.4)$ & $11(4 \cdot 7)$ & 0.82 & 0.56 \\
\hline All reactions & $210(23 \cdot 2)$ & $61(24 \cdot 8)$ & $127(14 \cdot 1)$ & $38(16 \cdot 2)$ & $<0.001$ & 0.02 \\
\hline
\end{tabular}

$\star 32$ subjects were excluded because of incomplete data, 10 of whom were at potential risk. 
TABLE III-Results of multiple regression analysis of the effect of independent variables on local and systemic adverse reactions. Data shown from full model and reduced model (incorporating only significant variables). Values are odds ratios ( $95 \%$ confidence intervals)

\begin{tabular}{|c|c|c|c|c|c|}
\hline \multirow[b]{2}{*}{ Variable } & \multirow[b]{2}{*}{ Code } & \multicolumn{2}{|c|}{ Systemic reactions } & \multicolumn{2}{|c|}{ Local reactions } \\
\hline & & Full model & Reduced model & Full model & Reduced model \\
\hline Vaccination & $\begin{array}{l}\text { Yes }=1 \\
\text { No }=0\end{array}$ & $1.13(0.83$ to 1.53$)$ & & $2.62(1.93$ to 3.57$)$ & $2.62(1.93$ to 3.57$)$ \\
\hline $\begin{array}{l}\text { Lung } \\
\text { disease }\end{array}$ & $\begin{array}{l}\text { Yes }=1 \\
\text { No }=0\end{array}$ & $1.95(1.24$ to 3.07$)$ & $1.89(1.22$ to 2.93$)$ & $2.24(1.46$ to 3.44$)$ & 2.23 (1.46 to 3.40$)$ \\
\hline $\begin{array}{l}\text { Heart } \\
\text { disease }\end{array}$ & $\begin{array}{l}\text { Yes }=1 \\
\text { No }=0\end{array}$ & $1.04(0.63$ to 1.71$)$ & & $1.57(1.02$ to 2.42$)$ & $1.56(1.02$ to 2.41$)$ \\
\hline Diabetes & $\begin{array}{l}\mathrm{Yes}=1 \\
\mathrm{No}=0\end{array}$ & $1.42(0.54$ to 3.71$)$ & & $0.90(0.31$ to 2.62$)$ & \\
\hline $\begin{array}{l}\text { Vaccinated } \\
\text { previously }\end{array}$ & $\begin{array}{l}\text { Yes }=1 \\
\text { No }=0\end{array}$ & $0.75(0.46$ to 1.22$)$ & & $0.94(0.61$ to 1.45$)$ & \\
\hline Sex & $\begin{array}{l}\text { Male }=1 \\
\text { Female }=0\end{array}$ & $0.47(0.34$ to 0.66$)$ & $0.47(0.34$ to 0.65$)$ & $0.38(0.28$ to 0.52$)$ & $0.38(0.28$ to 0.52$)$ \\
\hline Age & Per year & $1.01(0.98$ to 1.04$)$ & & $0.97(0.94$ to 0.99$)$ & $0.97(0.94$ to 0.99$)$ \\
\hline $\begin{array}{l}\text { Constant (nat } \\
\text { antilogarith }\end{array}$ & & $0.06(0.01$ to 0.39$)$ & $0.141(0.116$ to 0.172$)$ & $0.94(0.15$ to 5.90$)$ & $0.96(0.15$ to 5.97$)$ \\
\hline
\end{tabular}

In conclusion, only local side effects were more common in patients given influenza vaccine than in those given placebo. As one man died because he believed that the pain in his left arm was a side effect of vaccination we recommend giving influenza vaccine in the right arm. Our findings in patients who were potentially at high risk are probably applicable to patients previously identified as high risk. All the side effects reported were mild, and it seems reasonable to advise vaccination of high risk patients.

This study was supported by a grant from Praeventiefonds, project number 28-2127. We thank the general practitioners and patients who participated in the study for their cooperation.

1 Van Veen WA. Influenzavaccinatie: hoe effectief is het beleid? Huisarts Wet 1990;33:415-6.

2 Hofstra MI, Ter Braak EM, Van der Werf GTh, Smit RJA. Een geautomatiseerd zoek- en oproepsysteem voor vaccinatie tegen influenza. Huisart Wet 1990;33:429-32. (Abstract in English.)

3 Centers for Disease Control. Influenza vaccination coverage levels in selected sites-United States, 1989. MMWR 1990;39:111-3.

4 Helliwel BE, Drummond MF. The costs and benefits of preventing influenza in Ontario's elderly. Can $\mathcal{F}$ Public Health 1988;79:175-80.

5 Govaert ThME, Dinant GJ, Knottnerus JA. Vaccinatie tegen influenza in een huisartspraktijk. Opkomst en vaccinatiegraad van risicopatienten. Huisars Wet 1991;34:478-81. (Abstract in English.)

6 Sprenger MJW, Beyer WEP, Ament AJHA, Rutten FFH, Masurel N.
Influenzavaccinatie leidt tot kostenbesparing in de gezondheidszorg Tijdschr Soc Gezondheidszorg 1987;65:222-5. (Abstract in English.)

7 Nickol KI, Lofgren RP, Gapinsky J. Influenza vaccinations, knowledge, attitudes and behavior among high-risk outpatients. Arch Intern Med 1992;152:106-10.

8 Eraker SA, Kirscht JP, Becker MH. Understanding and improving patient compliance. Ann Intern Med 1984;100:258-68.

9 Ganguly R, Schler S, Vargas L, Cameron D, Chmel H, Benhke RH, et al. Reasons for non-immunization against influenza in the aged. $f \mathrm{Am}$ Geriat Soc 1989;37:387.

10 Mostow SR, Schoenbaum SC, Dowdle WR. Studies with inactivated influenza vaccine purified by zonal centrifugation. I. Adverse reactions and serological response. Bull World Health Organ 1969;41:525-30.

11 Ruben FL, Jackson GG. A new subunit influenza vaccine: acceptability compared with standard vaccines and effect of dose on antigenicity. $\mathcal{f}$ Infect Dis 1972;125:656-64.

12 Mostow Sr, Eickhof TC, Chelgren GA, Retaillou HF, Castle M. Studies of inactivated influenza virus vaccines in hospital employees. $\mathcal{f}$ Infect Dis 1977;136:S533-8.

13 Margolis KI, Nichol KL, Poland GA, Pluhar RE. Frequency of adverse reactions to influenza vaccine in the elderly. A randomised, placebocontrolled trial. FAMA 1990;264:1139-41.

14 Margolis KL, Poland GA, Nichol KL, MacPherson DS, Meyer JD, Korn JE et al. Frequency of adverse reactions after influenza vaccination. $\mathrm{Am} \mathcal{F}$ Med 1990;88:27-30.

15 Scheifel DW, Bjornson G, Johnston J. Evaluation of adverse events after influenza vaccination in hospital personnel. Can Med Assoc $\mathcal{f}$ 1990;142. influenza.

16 Palache AM. Influenza vaccination. The effect of dose and age of the antibody response (thesis). Rotterdam: Erasmus Universiteit Rotterdam, 1991.

17 Palache AM, Beyer WEP, Sprenger MJW, Masurel N, Jonge de S, Vardy A et al. Antibody response after influenza immunisation with various vaccin doses. A double blind, placebo controlled, multicentre, dose-response stud in eldery, nursing home residents and young volunteers. Vaccine 1992;11 3-9.

18 Alling DW, Blackwelder WC, Stuart-Harris CH. A study of excess mortality during influenza epidemics in the United States, 1968-1976. Am $\mathcal{F}$ Epidemiol 1981;113:30-43

19 Barker WH, Mullooly JP. Impact of epidemic, type A influenza in a defined adult population. Am $\mathcal{F}$ Epidemiol 1980;112:798-811.

20 Barker WH, Mullooly JP. Pneumonia and influenza deaths during epidemics. Implications for prevention. Arch Interm Med 1982;142:85-9.

21 Sprenger MJW, Mulder PGH, Beyer WEP, Van Strik R, Masurel N. Impact of influenza on mortality regarding age and entity of underlying disease during the period 1967 to 1989. Int I Epidemiol 1993;22:333-9.

22 Sprenger MJW, Desmyter J, Masurel N. Minderheids-standpunt over influenzavaccinatie bij ouderen. Ned Tijdschr Geneeskd 1991;135:2208-10.

23 Gezondheidsraad: Commissie vaccinatie tegen influenza. Vaccinatie tegen influenza; seizoen 1991-1992. Den Haag: Gezondheidsraad, 1991/15.

24 Parkman PD, Galasso GJ, Top FH, Noble GR. Summary of clinical trials of influenza vaccines. F Infect Dis 1976;134:100-7.

25 LaMontagne JR, Noble GR, Quinnan GV, Curlin GT, Blackwelder WC, Smith I, et al. Summary of clinical trials of inactivated influenza vaccine1978. Rev Infect Dis 1983;5:723-36.

26 Masurel N, Laufer J. A one-year study of trivalent influenza vaccines in primed and unprimed volunteers: immunogenicity, clinical reactions and protection. Foumal of Hygiene 1984;92:263-76.

27 Cate TR, Kasel JA, Couch RB, Six HR, Knight V. Clinical trials of bivalent influenza ANew Jersey/76-A/Victoria/75 vaccines in the elderly. $\mathcal{f}$ Infect Dis 1977;136(suppl):5518-25.

(Accepted 23 September 1993)
How medically incapacitated does a patient have to be before he or she can justly claim to be unable to provide a breath specimen for a Lion Intoximeter for the police, and which clinical tests are available to help measure that degree of incapacity?

In clinical forensic practice the claim of inability to provide a breath specimen when a Lion Intoximeter or similar device is used usually results in the police asking for a blood or urine sample for analysis. If this is refused and at a subsequent court appearance there is an argument as to the subject's ability to blow, the medical evidence will depend on a clinical assessment. In all cases a clinical examination should be performed and, if possible, lung function assessed by spirometric tests. This facility rarely exists in police stations, and the examining doctor will have to rely on subsequent assessment.

The minimum breath volume required for the Lion Intoximeter 3000 has been set at 1.5 litres, and this must be provided in a breath not exceeding nine seconds' duration. In one survey quoted $3 \%$ of subjects tested experienced difficulty in satisfying the requirements of the breath test instrument. ${ }^{1}$ It was noted that when absolute values for forced expiratory volume in one second were below $2 \cdot 0$ litres or the forced vital capacity was below 2.6 litres failure generally occurred whether the patient suffered from diseases causing airways obstruction-for example, chronic bronchitis and asthma-or diseases which restrict lung volumes, such as a fibrosing alveolitis and sarcoidosis.

There can be large variations in pulmonary function in people with asthma even in a 24 hour period. So these people may be able to use breath testing devices on one occasion but not on another, depending on whether bronchospasm is present and also on its degree. Episodes of acute infection in chronic bronchitis may also increase airways obstruction. People with inadequately controlled congestive cardiac failure and those who have had a pneumonectomy must also be borne in mind.

The clinical test of choice is spirometric measurement of forced expiratory volume in one second and forced vital capacity; the operator must give the subject adequate instruction in the technique of carrying out the test efficiently and must also assess the degree of genuine effort made by the subject at the time. I would not advocate use of the peak expiratory flow rate as an effective measure of ability to use breath testing devices.-RALPH A A R LAWRENCE, senior principal forensic physician to Derbyshire police.

1 Gomm PJ, Osselton MD, Broster CG, Johnson NM, Upton K. Study into the ability of patients with impaired lung function to use breath testing devices. Med Sci Law 1991;31:221-5. 